tion, then with incredulity and finally with suspicion. It was thought that a practical joke may have been played upon him by an assistant, but according to Sir James French, who as a boy knew Hannay and who remembers the circumstances of the experiment, Hannay was well aware of this possibility and guarded against it. Hannay repeated the experiments a year later, using various tube linings; and he claimed success in four out of thirty-four experiments at this later stage. Other scientific workers accepted the experiment as genuine but believed that the crystals obtained were a carbon-rich form of carborundum, which is not unlike diamond in structure, appearance and properties. So late as 1902 Hannay indignantly refuted this suggestion, which had been made in the "Encyclopædia Britannica" of that date. An X-ray investigation of the twelve crystals preserved at the British Museum has proved definitely that eleven of them are diamonds; many of them show striations similar to those found on type II diamonds, and a special investigation of one specimen has proved that it is, in fact, a type II diamond. In spite of its minute size (less than $0.05 \mathrm{mgm}$. or 0.00025 carat) it is an excellent reflector, but it shows no signs of the type I streaks or triangles, although it shows the 'thermal spot' common to all diamonds. Although type II diamonds are com. paratively rare in Nature, it is this mosaic type that one would expect to be formed under the relatively hurried conditions of a laboratory experiment. We can prove that the crystals are diamonds, but we cannot prove that Hannay made them. All things being considered, however, it seems only right to assume that he did; the matter was discussed at length in the correspondence columns of NATURE in 1943.

In some ways the problem of diamond is like a crossword puzzle. We have clues, but in some cases we do not know the solution; in other cases there seem to be more than one possible solution. But as Sir William Bragg said many years ago : "There is no cross-word puzzle that can compare in interest with the practical working out of a problem in Physics or Chemistry. You may say that to work at an amusing thing is not a very noble task. I can only answer that it makes a very happy life and I think that, if we can increase the number of human beings who find happiness in their work, we shall have gone some way towards creating a better state of things."

\section{CHUNGKING INDUSTRIAL AND MINING EXHIBITION}

\section{By Dr. JOSEPH NEEDHAM, F.R.S. British Scientific Mission in China}

$\mathrm{D}$ URING March an important Exhibition of Technology organized by the National Resources Commission (part of the Chinese Government's Ministry of Economic Affairs) was held in Chungking. This exhibition, which has attracted daily many thousands of visitors, deserves a world attention wider than the interest of the inhabitants of the Chinese capital, since it signalizes in a striking way the determination of China to embark upon largescale industrialization, by which alone the standard of life of the masses in China can be permanently raised.
The exhibition occupied large and spacious halls, specially constructed for the occasion entirely of bamboo poles and matting, and set up on the campus of the Chiuching Middle School in pleasant surroundings. Facing the visitor in the imposing entrance-hall were the devices (acting as badges stimulating esprit de corps, as well as trade-marks) of the 105 mines and industrial plants operated by the National Resources Commission in Free China, that is, in the south-east, south-west and north-west parts of the country. The Commission employs some 170,000 workers, part of whom are skilled, and 12,000 staff, of whom some 42 per cent are trained engineers, chemists, etc., and 23 per cent in the administrative division. The walls of the entrance-hall were covered with maps and charts, and below were displayed a remarkable collection of mineral geological specimens, arranged with the aid of the Chinese Geological Survey. Here it may be observed that China produces 70 per cent of the world's antimony. Here one could handle a specimen of the ponderous tungsten ore, wolframite, of which China is the leading world producer. In the centre of the hall was an exhibit which should have been very educational for the Chinese public - a display of all the old provincial weights and measures side by side with the standard measures of weight and capacity. The importance of standardization was also shown by a medley of pieces of electric equipment, none of which will fit each other, presumably the result of pre-war purchases from Western countries, and showing the necessity of one standardized industry for all China. An idea of what standardization means was also given by a well-arranged exhibit of gun parts supplied by the arsenals of the Chinese Ordnance Administration.

\section{Mining and Metallurgy}

Proceeding along his fixed path, the visitor came next to the section on coal and oil. Here there were excellent stratigraphic mine models, pictures of types of transport, and a historical series showing the evolution of the miner's lamp in China from the Roman-style oil wick to the modern battery light. In the oilfield section, there was a magnificent model of the Kansu field in its desert mountains, and a number of working models not only of drilling derricks (about $6 \mathrm{ft}$. high) but also of the refinery. There were also actual specimens of the drilling bits and jigs, and a display of the various refinery products.

After this, the visitor reached the iron and steel section. There was a short historical exhibit going back to ancient Egyptian iron technology, and ending with modern metallographic pictures. The model blast furnaces were particularly fine, standing about $10 \mathrm{ft}$. from the ground and complete in every detail. One in particular was of interest as the original was largely built out of steel plate salvaged from riversteamers destroyed by bombing.

The metallurgical department continued into the non-ferrous metals section, which was particularly good. The display of specimens of economic minerals in the entrance hall, to which reference has already been made, was repeated on a smaller scale in each of the non-ferrous and mining halls; a very fine educational idea, since anyone who failed to take in the full import of the various minerals when he first saw them, could turn aside from the metallurgical models and familiarize himself with the ores on which the industries are based. Interesting copper-aluminium alloys with properties similar to nichrome steel were shown by the Electrochemical and Metallurgical 
Works at Sanchi under the direction of Dr. Yeh Chu-Pei (Yap ChuPhay). This same works recovers zinc and copper from the bronze coins of former dynasties, of which a large stock has been collected, as well as smelting the native ores. It also produces copper of ordnance standard by electrolytic purification, of which an excellent working model was shown. Bauxite has now been discovered in Yunnan and Kweichow provinces, and an ingot of aluminium bears the triumphant inscription "The first Al sample industrially produced in China, at 4.30 p.m. on Dec. 11th, 1943"'. The sump mining of cassiterite tin ore was illustrated by an excellent timber model showing the washing troughs, and there was a working model of a tin smelting and purification plant. In the washing of wolframite ancient traditional wooden implements are used, also shown in model form. Particularly interesting is the technology of mercury. There were beautiful specimens of einnabar, that precious substance of the early Chinese

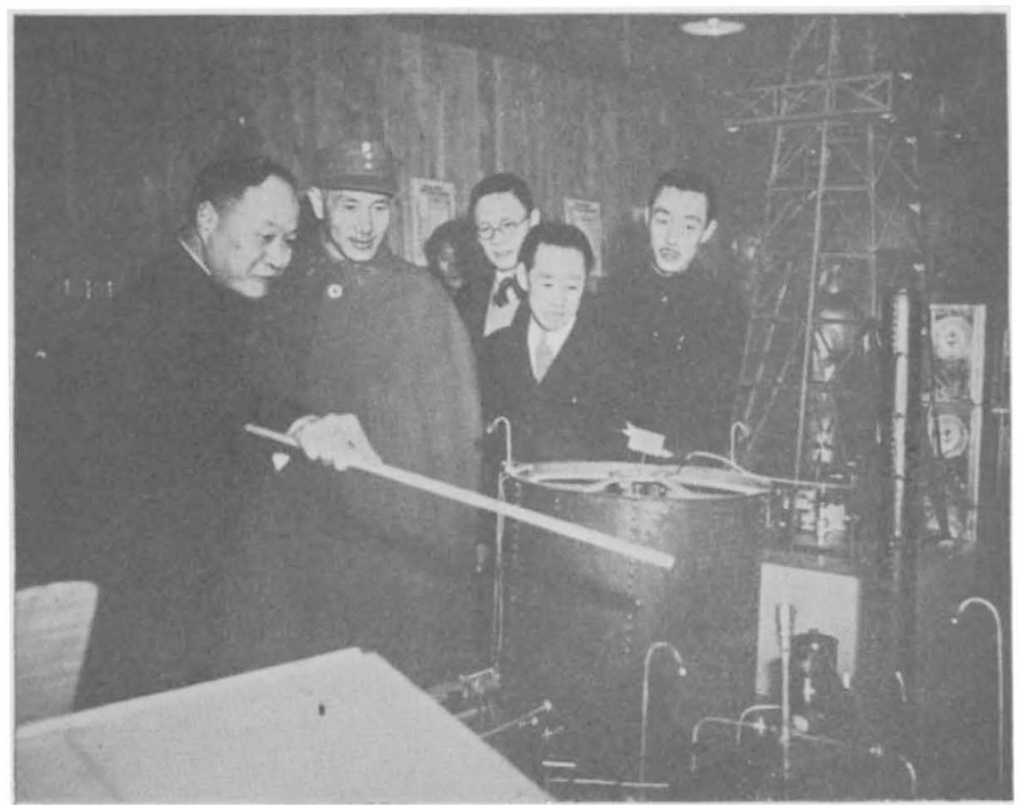

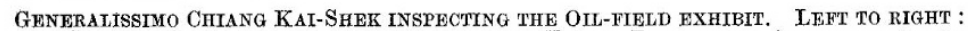
DR. SUN YU-CHI, GENERAL MANAGER OF THE KANSU PETROLEUM ADMINISTRATION ;

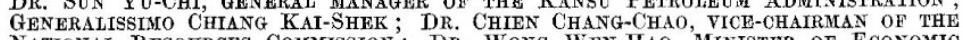
DONG WEN-HAO, MINISTER OF ECONOMIO AFFAIRS AND CHATRMAN OF THE NATIONAI RESOURCES COMMISSION.

alchemists, and a series of models illustrated the different types of traditional smelting furnaces used in the different provinces. Finally, the antimony industry showed antimony ingots and models of paint-production plants.

Leaving the metallurgical section, one entered that of the refractories, where a large variety of heatresistant bricks and acid-resistant stoneware was shown. There was a good display of China-made Seger cones.

\section{Chemical Industry}

Next came the chemical industry. The production of power alcohol, so wisely encouraged as a contribution to blockaded China's supply of transportation fuel, was represented by a fine series of models, notably that from Dr. Chang Chi-Hsi's plant, and good exhibits, both on the chemical and the mycological sides. The production of petrol by cracking vegetable oils, the other main contribution to the fuel supply, was illustrated by a working model of a pipe-still, cracking chamber, and fractionating column, made entirely of glass, from the Tungli works (Dr. Hsu Ming-Tsai and Dr. Sun Tsun-Chueh). On an adjacent stand, surrounding a young tung oil tree, were shown all the products which may be (and, in most cases, are being) made from the oil, such as candles, margarine, vanishing cream, paint, varnishes, printing inks, solvents, lubricating oils, plastics, kerosene, petrol, Diesel oil, tar, and even oil-resistant synthetic rubber (through ethylene to thiokol). When tung oil petrol is no longer needed after the War, it should still be possible to base a great industry on the tung oil plantations.

\section{Engineering}

The electrical industry exhibits were arranged around a circular domed hall, indirectly lit, and with grass and herbs strewn on the ground. Music for the whole exhibition was provided by Chinese-made radio gramophones in the radio section. Among the great variety of apparatus shown in the hall one noticed aviation ground-station equipment transmitters of $20-100 \mathrm{~m}$. frequency range (input $2 \mathrm{~kW}$. : output $\frac{1}{2} \mathrm{~kW}$.); short-wave broadcasting transmitters for interprovincial communications (input $4 \mathrm{~kW}$.: output $1 \mathrm{~kW}$.) ; scrambler sets; radio beacon transmitters; military walkie-talkie sets with bamboo aerials; hand and 1.h.p. motor generators; 5-tube superhet receivers; 8- and 10-tube communications receivers (pronounced by an expert to be as good as any in the world); universal meters for currents and resistances; 50-watt public address system amplifiers; a very large assortment of radio valves; telephone exchanges with the receivers of lacquered wood owing to the plastics shortage; motors and switchgear; and intercommunication telephones. On an average, $88 \cdot 3$ per cent of the component parts of all this apparatus was made entirely in China; only in the case of some valves and meters are the Chinese still dependent on imports from abroad. They hope to raise the figure to 97 per cent this year. Besides all this apparatus, there was a wealth of wire and cables of all sizes, electric bulbs, dry cells and batteries, telegraph insulators and hightension devices, silk- and rubber-covered flex, large accumulators made of wood and covered on the inside with an acid-resistant tung oil paint. One very educative exhibit was an illuminated circuit-diagram of a radio set actually working, and another was a flowsheet with all the component parts and their method of manufacture inserted. The biggest piece of Chinese-made apparatus in this section was a $1,200 \mathrm{kVA}$. step-up transformer for use in a phos. phorus factory. Very good porcelain lamp sockets and switches of simple design replace plastic ones.

No less impressive than the preceding sections was that devoted to hydraulic power. The existing and planned power grids were shown on very clear maps, and there were a number of beautiful topographic running-water models which strikingly explain how various natural features in river flow can be made 


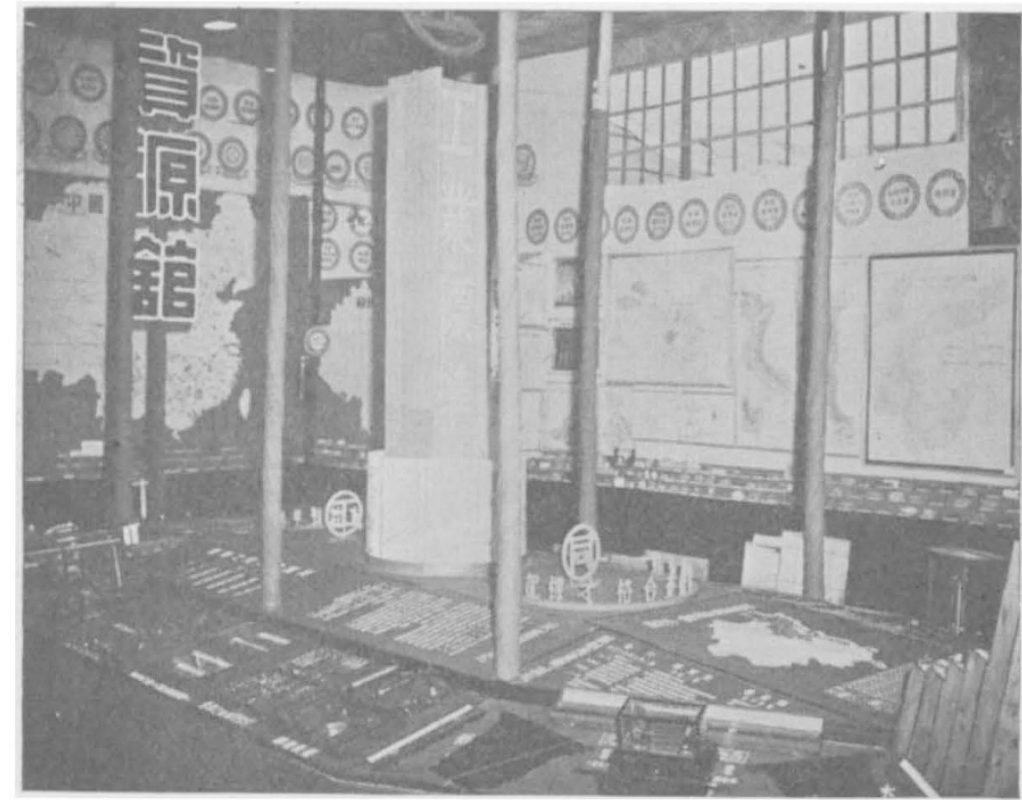

ENTRANCE HALI, WITH GEOLOGTCAT MAPS AND COLLEOTIONS IN THE BACKGROUND AND THE STANDARDIZATION EXHIBIT IN THE FOREGROUND.

farthest corner contained the exhibit of precision tools and machine tools. The former included many items in common use such as lathe and drill chucks, gear cutters and hobs, micrometers and surface plates, while the latter included bench motor drills, drill presses, lathes, shapers and milling machines. Many of the items exhibited in this section were produced by China's biggest machine works, that at Kunming, directed by Dr. Wang Shou-Chin.

Throughout the exhibition the visitor noticed from time to time interesting photographs showing the welfare for the personnel (hospitals, schools, pithead baths, and the like) undertaken by the various plants. In this respect, the National Resources Commission stands as a striking example to private firms in Chinese mining and industry, where the workers' conditions are some. times still in a distinctly backward state. Those who, like the present writer, have had the privilege of

use of. Thus the Changshou plant has no dam, but a mill-race channel some $2 \mathrm{~km}$. long, partly roofed as protection against land-slides, and leading to a penstock of $43 \mathrm{ft}$. fall. At Wanhsien, on the other hand, there is a low dam on top of a natural rock waterfall, and a rock-cut tunnel giving a fall of $45 \mathrm{ft}$. and an output of $300 \mathrm{~kW}$. At Shanyuting the mill-race channel is carried over a side-stream by a viaduct before it reaches the penstocks, and gives rise to $1,500 \mathrm{~kW}$. At Taohuachi the tunnel euts across the short side of an isosceles triangle made by the river, short-circuiting several natural falls, and achieving a penstock fall of $270 \mathrm{ft}$. giving $900 \mathrm{~kW}$. Some idea of the planned capacity of these west China networks may be gained from the following figures : visiting many of the plants under the National Resources Commission, know that these pictures are no mere propaganda, but do actually represent the facts.

\section{The Future}

A Western man of science came away from the Exhibition with two main impressions. In the first place, from what has been said above, it is clear that under the vigorous direction of Dr. Wong Wên-Hao, Minister of Economic Affairs and chairman of the National Resources Commission, and Dr. Chien Chang-Chao, vice-chairman of the Commission, the Chinese people have now the embryo (and by no means at a very early stage) of a Science Museum on

\begin{tabular}{|c|c|c|c|}
\hline zechuan & & & \\
\hline zechuan & & & 700,000 \\
\hline Kweiyang (Kweichow & & 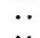 & $\begin{array}{l}90,000 \\
50,000\end{array}$ \\
\hline Djenbei & $\because$. & $\because$ & $\begin{array}{l}175,000 \\
\end{array}$ \\
\hline siangchung $\because$. & $\cdots$ & & 370 \\
\hline$\because \ddot{1}$ & . & 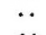 & 320,000 \\
\hline bi (I & & & \\
\hline
\end{tabular}

Not without interest, too, were the models of the high-tension line methods employed, the pylons being constructed mainly of wood.

The last section was that of mechanical engivieering, showing the products of the different machine works. One saw first three models of power plants manufactured in China recently, namely, one $2,000 \mathrm{~kW}$. boiler plant and two 150 h.p. water turbine and generator sets. On the other side were exhibited an actual six-cylinder stationary Diesel engine and generator set of 300 h.p. and one 10 h.p. gas engine set. Next in line came the various types of industrial machinery and motorvehicle parts and also a set of village cotton-spinning machinery. The

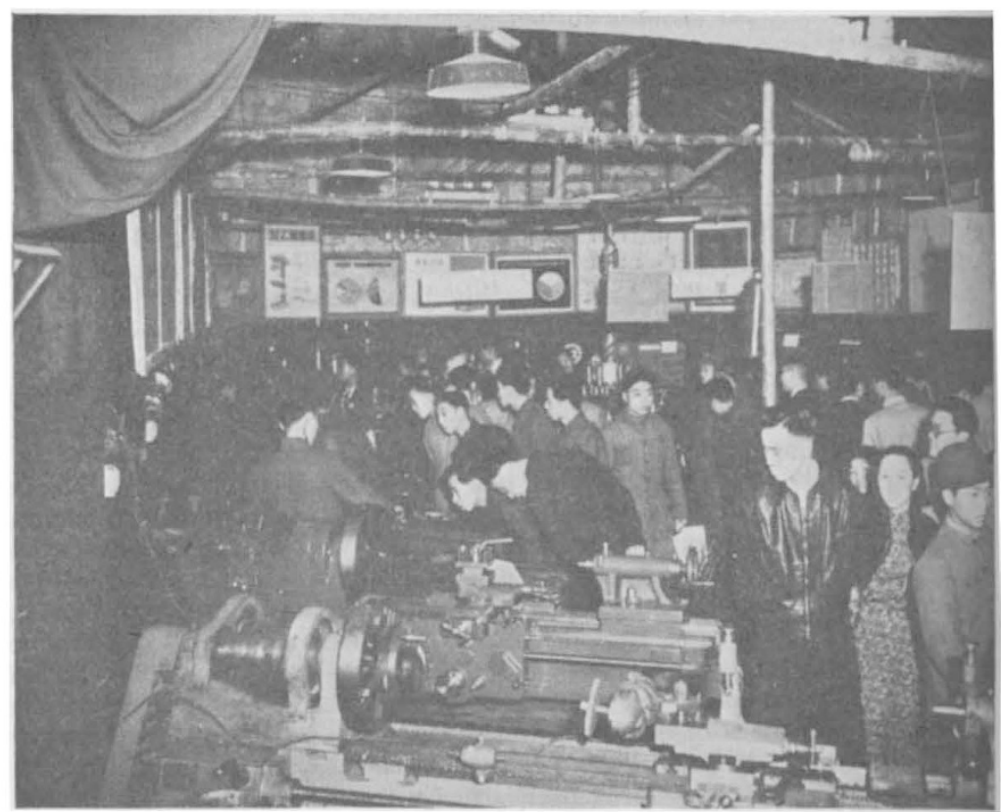

Section of Meghanicat Engtneering. 
the lines of South Kensington. It would be a disaster if all these models and collections, now so carefully assembled, were to be dispersed or lost, and all those interested in science and technology in other lands will agree with $m e$ in hoping that some arrangements will be made for preserving the present exhibition as a germ of a Chinese National Museum of Science and Technology. I am informed, indeed, that it is likely that some such arrangements, in conjunction with the Ministry of Education, will be made.

The second, and more far-reaching, point is, of course, that the Exhibition demonstrates, once and for all, that given the tools of the trade, Chinese technologists, engineers and scientific men are the equal of any in the world. To me, not unfamiliar with them beforehand, this came as no surprise, but it is a point which ought to be brought home to all those in Western countries who are concerned with post-war trade relations with China. Any idea that the Chinese are personally unfitted for technology and industry is a complete illusion. Any idea that they do not wish to industrialize their great country and will for ever be content to accept the industrial products of other countries is also a fatal mistake. They deserve, and should receive, every help in their industrialization. It was interesting to hear the comment of a Western diplomat who had spent many years in Japan, that in spite of the muchvaunted industrialization of that country, he had never seen there so well-arranged a technological exhibition.

At the present time, Chinese science and technology are encountering formidable obstacles. There is the state of blockade, which prevents the importation of essential apparatus if of any considerable weight; and there are the difficulties of transportation within the country, which lead to serious bottlenecks in raw material supplies; but worst of all is the financial situation, which renders all book-keeping so difficult and impedes all attempts, not only to attain all-out production, but even to reach the capacity production of the plants which have been set up with so much pain, trouble and technical skill. It seems that some urgent economic assistance is needed in this direction. Officials of the National Resources Commission say modestly that their efforts have been directed mainly to training cadres of technical men, a policy which will naturally bear fruit after the War rather than now. Nevertheless, her allies ought to find some way of aiding China to attain an all-out industrial production such as they themselves are able to carry on in the war against the Axis.

But in general, the point to be emphasized is that the Exhibition was a triumphant vindication of the technical excellence and competence of Chinese scientific and industrial workers. As such the world should take note of it. Not that the Chinese are latecomers to the world of industry. Their ancestors were using ploughs of iron when ours were using wooden ones, they printed long before Guthenberg, knew of gunpowder long before Schwarz, and made porcelain long before Pallissy. But until modern, theoretical science was born, all such achievements remained purely empirical; and modern industrialization is not, and could never have been, based on purely empirical knowledge. The Chinese, therefore, have to master applied science as a whole, just as Westerners have done. The recent Exhibition showed that they are, what John of Monte Corvino called them four hundred years ago, "di nostra qualite".

\section{J. B. VAN HELMONT (1579-1644) BY Dr. W. PAGEL}

TEAN BAPTISTE VAN HELMONT, the great Flemish natural philosopher, died three hundred years ago, at the age of sixty-five, bringing to a close a life embittered by religious persecution, but rich in inward contentment derived from sincere piety and a magnificent record of discoveries and ingenious conceptions in science and medicine. He devised one of the early thermometers. He proposed a reform of time measurement by the use of the pendulum and. devoted much work to the investigation of its laws. $\mathrm{He}$ endeavoured to express vital phenomena in chemical terms and thereby became one of the founders of biochemistry. He demonstrated that acid is associated with digestion in the stomach and alkali in the duodenum. He was one of the initiators of modern pathology, which he sought to base on a study of the external agents in relation to local changes in the organs in disease. This led him to a refutation of the "Folly of Catarrh"- the title he gave to one of his treatises-for it was then believed that many diseases were due to a flow of mucus from the brain straight through the base of the skull to all parts of the body, notably to the lungs and joints, causing consumption, rheumatism, pneumonia, gout. He even made practical contributions to clinical medicine, for he examined the specific gravity of urine and demonstrated the presence of carbon dioxide and ferrous oxide in the waters of Spa by means of evaporation.

In connexion with the discovery of 'acid fermentation' in the stomach, it is worth while recalling the theories of Paracelsus (1493-1541), which admittedly stimulated Van Helmont's work. Paracelsus recognized different digestive properties in the various digestive organs, such as mouth and stomach ("Opus Paramirum", III), and described the powerful support of gastric digestion by intake of acid, notably those found in spas', but did not regard acid as a normal secretion of the stomach, except in the case of the ostrich, which is thus able to digest metals. The 'fermenting' action of acid, for example, in food, had already been mentioned by Galen ${ }^{2}$, but up to Van Helmont's time and for a long time after, 'heat' and 'trituration' were believed to be the actual forces of digestion in the stomach.

Critical evidence has been given ${ }^{3}$ of Van Helmont's achievements in chemistry, of the quantitative character of his work, of his extensive use of the balance. These gave him insight into the indestructibility of matter. Thus he showed, for example, that metals are recoverable without loss of weight after solution in acid. He realized, moreover, that when one metal precipitates another from a solution of a salt there is no transmutation. He also made a clear distinction between copper and iron vitriols ${ }^{4}$.

Van Helmont studied volatile bodies with particular care. The achievement by which he is specially remembered is the separation from air and water vapour of a "New Entity" which he called "Gas". This "new entity" involved a change in the general concepts of biology, of medicine and indeed of cosmology and philosophy ${ }^{5}$. Such implications emerge with any attempt to restore the original setting in which the discovery was presented.

'Gas' appears first of all to be something 'specific' to the object in which it was contained. It is thus in contrast to volatile bodies such as air and water vapour, of which all objects in Nature may partake. Van Helmont sees gas as the vector of a specificity 